\title{
Graduate Conversations: Assessing the Space Needs of Graduate Students
}

\section{Kirsten Kinsley, Rachel Besara, Abby Scheel, Gloria Colvin, Jessica Evans Brady, and Melissa Burel}

This article discusses the preferences, habits, and needs of graduate students as they relate to spaces for research and study. The findings are based on a large-scale ethnographic study of graduate students at Florida State University conducted between 2010 and 2013. Using a variety of ethnographic methods, researchers found that graduate students have diverse needs and unequal access to appropriate spaces and resources to meet those needs. Libraries can help fill the gaps left by home and academic departments by providing a range of spaces offering different noise levels, resources, and other amenities.

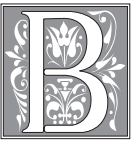

etween 2010 and 2013, Florida State University Libraries (FSUL) conducted a study to broaden its understanding of graduate students' academic work behaviors and needs. Recognizing that graduate students have different roles and responsibilities from undergraduate students, FSUL librarians wanted to ensure that they were providing the spaces, services, and resources that graduate students need to be successful. Using ethnographic methods allowed the librarians to gain a more complete understanding of graduate students' lives, allowing them to see better all the factors that can contribute to or impede graduate student success. This analysis explores the implications of graduate students' preferences, behaviors, and needs for spaces to research and study, because space-related issues were frequently discussed in the study and are a topic of key importance for libraries.

\section{Background}

Florida State University (FSU) is a Carnegie RU/HV (Research I) institution offering degrees in 76 doctoral, 115 masters, 23 specialists, and two professional programs. In

Kirsten Kinsley is Assessment Librarian, Rachel Besara is Director of STEM Libraries, Abby Scheel is Humanities Librarian, Gloria Colvin is Head of Scholars Commons, all at Florida State University Libraries,e-mail: kkinsley@fsu.edu, rbesara@fsu.edu, ascheel@fsu.edu, and gcolvin@fsu.edu; Jessica Evans Brady is Research $\mathcal{E}$ Collections Librarian in the Fine Arts Library at Harvard University, e-mail: jevansbrady@ fas.harvard.edu; Melissa Burel is Catalog Librarian in Library \& Information Services at Southern Illinois University Edwardsville, e-mail: mburel@siue.edu. Acknowledgments: The authors would like to thank Rebecca Bichel, former Associate Dean for Public Services at Florida State University Libraries, the many library staff members who helped collect and transcribe the data, and the study participants for supporting this study. (C2015 Kirsten Kinsley, Rachel Besara, Abby Scheel, Gloria Colvin, Jessica Evans Brady, and Melissa Burel, Attribution-NonCommercial (http://creativecommons.org/licenses/by-nc/3.0/) CC BY-NC. 
fall 2012, there were 8,155 graduate and professional students enrolled, accounting for approximately 20 percent of the total student population. ${ }^{1}$

In 2006, FSUL reorganized its Public Services division to focus on serving the needs of different user populations. The Scholars Commons became a department with services and spaces designed to cater to the needs of graduate students and faculty. The lower floor of the seven-floor main library was renovated in 2008 to include some dedicated quiet study spaces, group spaces, conference rooms, and a computer lab for these scholars so that they would not have to compete with the large undergraduate population for library space. ${ }^{2}$

In 2010, library administration charged a newly formed assessment department with conducting an ethnographic study of the graduate student population. Earlier assessment efforts included limited interviews with graduate students and data from LibQUAL+ and internal surveys, but this study would be more comprehensive in scope. Librarians sought to determine whether the services, resources, and spaces the libraries provided to graduate students effectively aligned with and supported their academic preferences, needs, and behaviors.

\section{Review of Selected Literature}

While large ethnographic studies have been conducted in libraries since the landmark Rochester study, ${ }^{3}$ few of these studies have adopted a holistic, multimethod approach to studying graduate student populations. ${ }^{4}$ Most studies of graduate students have focused on specific themes, such as their research needs, how they use the library, how to design a better library website, or how to build a more attractive institutional repository. ${ }^{5}$

It is difficult to summarize graduate student behaviors and needs. Covert-Vail and Collard identified graduate students as a "heterogeneous" group. ${ }^{6}$ The differences within the graduate student population stem from demography, age and life stage, or program of study. Students' needs and behaviors change significantly over the course of their graduate school careers. Researchers find that masters students have different needs from doctoral students; furthermore, the needs of students taking courses differ from those of students working on a thesis or dissertation. ${ }^{7}$ Graduate students can find it especially difficult to find a work/life balance because they find themselves filling multiple roles, such as spouse, parent, student, teacher, employee, researcher, and so on. ${ }^{8}$ Combined with these factors, even small barriers can become significant challenges. ${ }^{9}$ For example, students may forgo learning how to use citation management software, which might save them time in the long run, because even the short-term time investment to learn the program appears too time consuming. ${ }^{10}$

Graduate students need flexible space to support their long and varied working hours, as well as space to accommodate different types of work, such as group or individual work. ${ }^{11}$ As the intensity of their research increases, so too does their need for space. According to Covert-Vail and Collard, "higher demands for synthesis of disparate resources, combined with technology-integrated working styles (laptops, tablets, etc.), means that the amount of space needed per graduate user is higher than it is for less research-intensive users." ${ }^{21}$ Storage is also part of the large footprint for graduate students and a key component as they continue to prefer print formats and tend to compile large collections of print and online research materials. ${ }^{13}$

Graduate students also pay attention to the atmosphere of a space and their surroundings. They desire a welcoming space with comfortable seating. ${ }^{14}$ Noise level is also an important consideration. ${ }^{15}$ Hunter and Cox found evidence regarding students' tolerance for noise and distractions: "The extent to which stimuli impact on students' studies varies greatly. Whilst some students find a stimuli engaging, others find the same stimuli overwhelming." 16 
Several studies have found that graduate students consider the library an important place for their schoolwork. ${ }^{17}$ For example, in a Boston University report, an overwhelming majority of graduate students considered quiet individual space and group work space in the library important. ${ }^{18}$ One commonly noted barrier to using the library is limited operating hours. ${ }^{19}$

Graduate student life revolves heavily around their departments, and the spaces available in the departments can have a significant effect on how and where graduate students work. In a study of graduate students at Oregon State University, Rempel, Hussong-Christian, and Mellinger found widespread differences in departmental resources and spaces, describing some departments as "the haves" and others as "the have nots." ${ }^{20}$ In their research on ARL libraries, Covert-Vail and Collard found "inequality among graduate students" within a department such as between masters and doctoral students. Furthermore, they determined that "library as place" tends to be more important for masters students who "tend to be more itinerant, more likely to have a job, to have families, and to be international students than their doctoral counterparts." ${ }^{21}$ A lack of departmental resources and spaces even among doctoral programs can lead to "great[er] reliance on the library" to meet those needs. ${ }^{22}$

Other places beyond home and the department also play an important role in graduate student life. Places like coffee shops, campus research centers, and libraries have been identified as "third spaces" where students can both work and interact with different groups of people..$^{23}$ These third spaces can help graduate students, who very often work independently, feel a sense of community with other serious-minded people working individually but in a similar fashion. ${ }^{24}$

\section{Methodology}

The study of academic work behaviors and needs of graduate students at FSU began in 2010. Recognizing that there is diversity among graduate students and their academic disciplines and schools, this study's researchers photographed, observed, and questioned students in areas where they congregate to gather information to guide library decision-making. These methods sought to answer the overarching question, "What are the academic work behavior patterns and needs of FSU graduate students?"

This study differs from other graduate ethnographies conducted by libraries in three respects: the use of more comprehensive and varied data-gathering techniques; a population-focused approach that included graduate students who may or may not currently use the libraries; and a holistic view of graduate students' lives. The number and types of methods used in this project more closely resemble those used to consider undergraduate study habits in Studying Students and Project ERIAL. ${ }^{25}$

This is the largest ethnographic study of graduate students undertaken by an academic library both in terms of sample size and methods. Graduate student subjects came from humanities and social sciences disciplines. ${ }^{26}$ The FSU study was conducted in two phases. Unlike other ethnographic studies done in libraries, subjects in the first phase of the study were not told that the researchers were from the libraries. This was done to gain a more authentic view of their academic work behaviors and needs, as well as to avoid auspices bias in their responses. ${ }^{27}$

Phase I of this study employed a 23-item survey, interviews, focus groups, photo diaries, charrettes (design drawings) of ideal spaces, and freeze frames (impromptu photos of graduate students at work) to illustrate how graduate students engage in research and study. ${ }^{28}$ Researchers went to places where graduate students spent time on and off campus to observe them in their typical work and study environments. Interview questions attempted to capture responses regarding the overall picture of students' academic work lives without any specific prompts about library 
use and tools. Regardless of whether subjects brought up the library, researchers were able to see how campus libraries fit within graduate students' daily research and study lives.

Phase II of the study was composed of interviews and focus groups conducted in library spaces by library staff. Graduate students were asked more specific questions related to their library-use patterns and preferences.

All studies were approved by the FSU Institutional Review Board. For each component other than the freeze frames, subjects were given an informed consent form

\begin{tabular}{|c|c|c|}
\hline \multicolumn{3}{|c|}{$\begin{array}{c}\text { TABLE } 1 \\
\text { Methodologies }\end{array}$} \\
\hline $\begin{array}{l}\text { Qualitative } \\
\text { Methods }\end{array}$ & Description & $\begin{array}{c}\text { Sample Size } \\
n=\end{array}$ \\
\hline $\begin{array}{l}\text { Phase I } \\
\text { Interviews }\end{array}$ & $\begin{array}{l}13 \text { questions on topics: departmental support, favorite } \\
\text { places to study/research, timing of research activities, } \\
\text { campus study/research places, and technology tools, etc. }\end{array}$ & 20 \\
\hline $\begin{array}{l}\text { Phase I Focus } \\
\text { Groups }\end{array}$ & $\begin{array}{l}\text { Topics: graduate student services and people; } \\
\text { environments and resources; tools and skills; } \\
\text { international and special student questions }\end{array}$ & 8 \\
\hline $\begin{array}{l}\text { Charrettes } \\
\text { (Ideal Space } \\
\text { Drawings) }\end{array}$ & $\begin{array}{l}\text { Subjects drew ideal research/study space and were } \\
\text { interviewed about their drawings. Prompts included: } \\
\text { room dimensions; windows; lighting; furniture; tools } \\
\text { and equipment; location situation; different from } \\
\text { current spaces; access. }\end{array}$ & 20 \\
\hline Photo Diaries & $\begin{array}{l}\text { Subjects took approximately } 22 \text { pictures based on } \\
\text { prompts about their technology and spaces use, } \\
\text { mentors, group work, barriers, faculty interaction, } \\
\text { and time management tools, etc. Subjects were also } \\
\text { interviewed about the photos. }\end{array}$ & 19 \\
\hline Freeze Frames & $\begin{array}{l}\text { Pictures of graduate students in off-campus locations } \\
\text { such as local coffee shops, apartments, etc. and in on- } \\
\text { campus teaching assistant offices, departments, etc. }\end{array}$ & $>15$ \\
\hline $\begin{array}{l}\text { Phase II } \\
\text { Interviews }\end{array}$ & $\begin{array}{l}\text { Interviews were conducted in the library with library- } \\
\text { specific questions; subjects knew interviewers were } \\
\text { library staff; questions were about the research process, } \\
\text { resources and services needed, how the library is used } \\
\text { in research, how obstacles are faced, what help they } \\
\text { seek, library support, and suggested library changes. }\end{array}$ & 20 \\
\hline $\begin{array}{l}\text { Phase II Focus } \\
\text { Groups }\end{array}$ & $\begin{array}{l}\text { Focus Groups were conducted in the library with } \\
\text { library-specific questions; subjects knew interviewers } \\
\text { were library staff; topics were about spaces and library } \\
\text { support services. }\end{array}$ & 28 \\
\hline $\begin{array}{l}\text { Quantitative } \\
\text { Method }\end{array}$ & Description & \\
\hline $\begin{array}{l}\text { Academic Work } \\
\text { Behaviors \& } \\
\text { Needs Survey }\end{array}$ & $\begin{array}{l}\text { 23-question survey e-mailed to entire campus, questions } \\
\text { focused on demographics, what work environments and } \\
\text { behaviors led to success and distractions. }\end{array}$ & $\begin{array}{l}1,029 \text { graduate } \\
\text { student } \\
\text { respondents }\end{array}$ \\
\hline Total & & 1,159 \\
\hline
\end{tabular}


along with an opportunity to receive an incentive, such as gift cards to bookstores or coffee shops. Approximately 1,059 subjects participated in this study (see table 1).

\section{Content Analysis}

To analyze the data while attempting to minimize researcher bias, the authors used a grounded theory approach. Due to the massive amount of data available, especially transcripts of interviews conducted for a given method coupled with corresponding photos or drawings, team members independently identified overarching codes or themes observed in a sample of the data. Researchers then met together and shared what they saw as overarching themes and subthemes across different study methods. Their analysis looked at the full scope of graduate lives that emerged, from research and creative work to advisors and cohorts, to budgets and transportation, and identified places where the library already fit in and opportunities where the library might fill a need. Choosing to focus on those areas where the data might be directly applicable to the library, space, resources, and services were selected as the overarching themes. These main themes and subthemes (such as lighting, furniture, technology, personnel) were defined, standardized, and applied to all of the studies. A pair of researchers independently studied each methodology and tracked the data on standardized spreadsheets. This verification of observations by at least two separate reviewers provided inter-rater agreement. Once reviewers coded the data and agreed on the findings, the team of researchers identified significant trends.

The qualitative data analysis software NVivo was also used to validate the researchers' observations of themes and the lack of researcher bias in identifying trends. Word frequency counts of variations of the terms "quiet," "distraction," and "library" in participants' comments were used to create word trees, which in turn provided a visual display of the context in which the concepts were used.

The overall data collected were too rich for every aspect to be addressed in a single article. Some topics touched upon by the data included work-life balance, barriers to success, resources used, transportation, budgeting, and teaching. However, in this analysis and following discussion, the researchers chose to focus on the issue of space, because this was the theme most fully and concretely discussed by participants and is a perennial concern for FSUL and libraries generally. This focus was considered broadly to include many factors that impact space needs, preferences, and desires. Other topics from the data may be explored in further articles.

\section{Results and Discussion}

As the researchers analyzed the data, a general profile of FSU graduate students emerged. While individual circumstances varied widely, the graduate students in this study also had much in common. The qualitative and quantitative survey data reinforced that a typical graduate student works long hours, seven days a week, and is very serious and dedicated to his or her work. Survey results show that 53 percent work from 16 to more than 30 hours per week. As recognized by Covert-Vail and Collard, as well as Rempel et al., they have many demands and roles "beyond being a mere student." ${ }^{29}$ As the data demonstrate, these demands include jobs, families, teaching, coursework, participating in conferences, and publishing. Given their busy lives, they often fit research and writing into the gaps left by other fixed obligations. This requires them to be flexible, and they may do their work at any time of day or night. Most often they work at home or in departmental spaces, followed by libraries and coffee shops. When engaged in academic work (such as research, study, or writing), survey respondents reported that they are most successful when they work in a private space $(76 \%)$ or alone $(88 \%)$. 
Departments are at the center of graduate students' experiences. They are places where students do their work as well as receive and share information about campus resources. The availability and quality of departmental work spaces provided for graduate students varied tremendously. Echoing the trend of "the haves" and "the have nots" most recently identified by Rempel, Hussong-Christian, and Mellinger, ${ }^{30}$ some graduate students in this study had offices while some did not. Some had an office one semester but not the next. Most shared offices with at least one other person. Departmental spaces ranged from small offices for one or two people to a large room lined with desks or cubicles for a cohort of graduate students (see figures 1 and 2). Some offices had a computer, while some did not. In addition, some departments provided a computer lab with specialized software. While these spaces can create community, the students interviewed indicated that these communal spaces can also foster distractions. Some students reported working in their department office at odd hours to avoid social distractions and alleviate cramped conditions. In cases where department spaces are inconsistent or inadequate, the findings show that graduate students often turn to the library to fill the gap.

Some graduate students referred to the library as a "second home" after their home department. ${ }^{31}$ Even students who were happy with their department spaces reported coming to the library for a change of pace, to meet with a group, or to access materials. For those without a department office, library spaces played an even more central role. However, some students rarely visited the library in person and instead relied heavily on the library's website and online resources. This feedback raised questions concerning the adequacy of the library's virtual presence but was beyond the scope of this analysis.

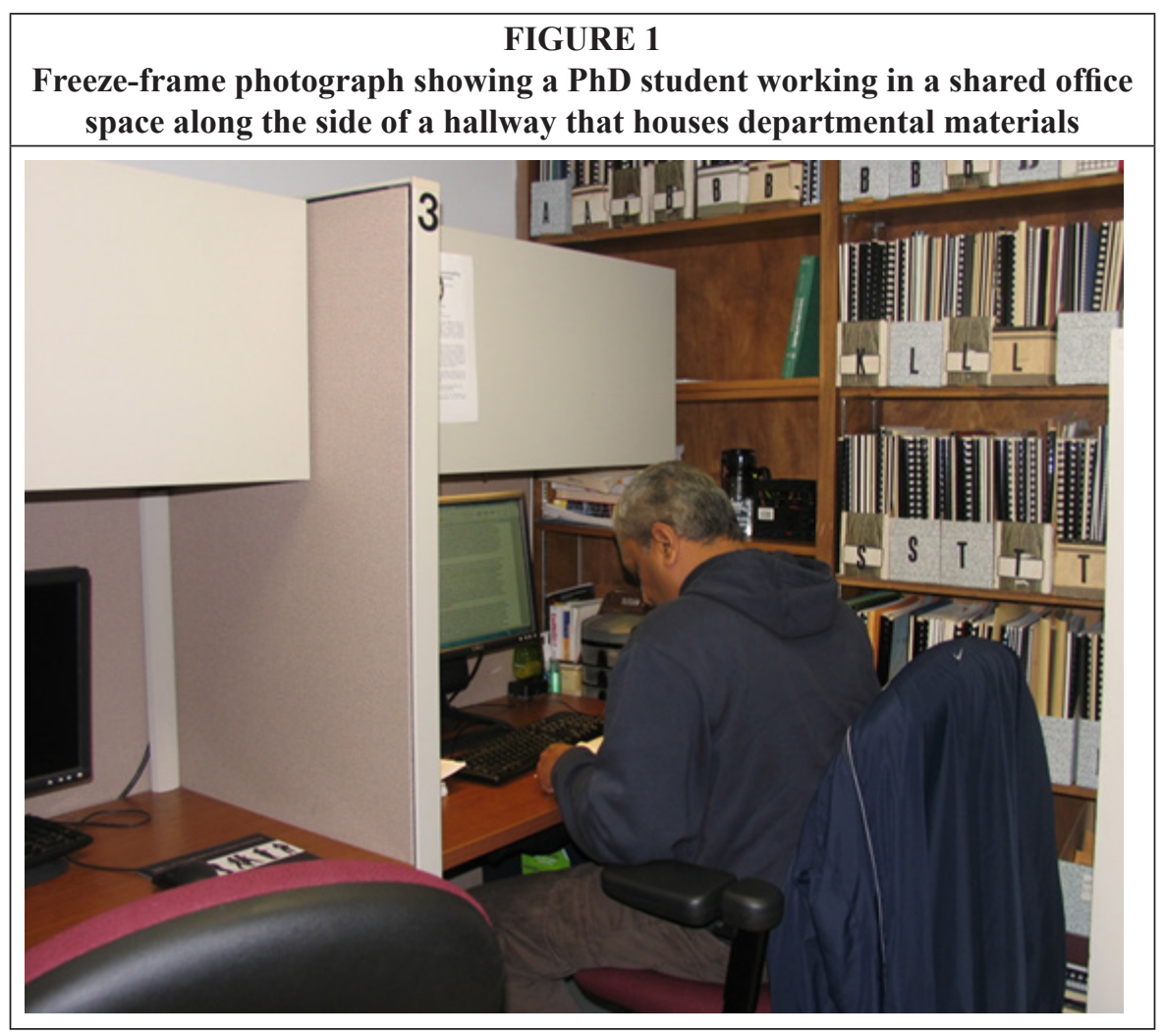




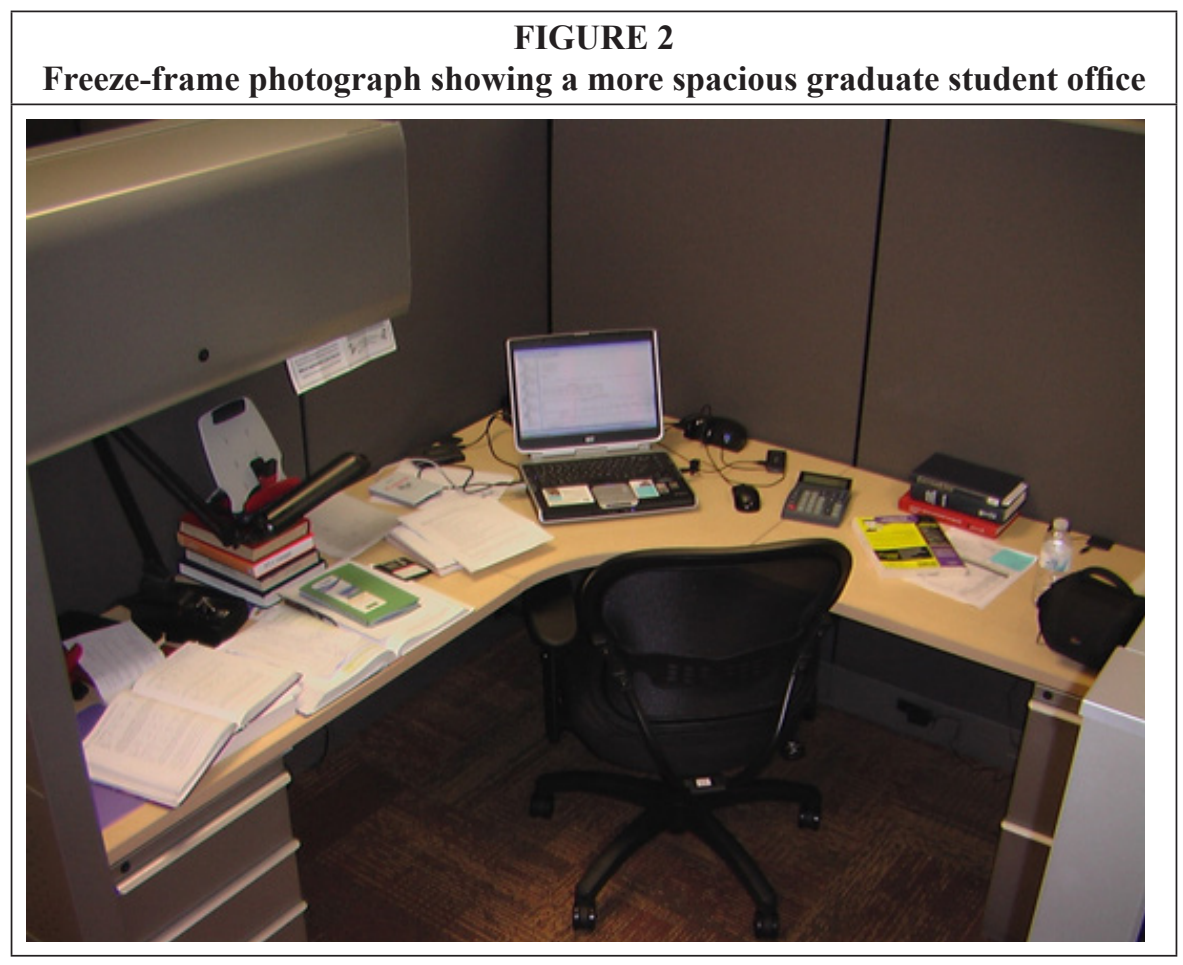

\section{Multiuse and Multifunctional Space}

Graduate students reported working on a wide variety of tasks and asked for a variety of spaces to suit whatever specific task was at hand. In addition to reading and writing, graduate research includes gathering, storing, and working with different types of data and software. Many graduate students work as teaching assistants, which involves preparing lectures, grading assignments, and meeting with students. As a result, students wanted a variety of spaces that served these functions.

The charrette drawings of ideal work spaces primarily revealed two types-a single multipurpose room and a suite of rooms dedicated to specific functions (see figures 3 and 4). For both types, the desired functions mainly fell into four categories: quiet work; group work; computer-based work; and relaxation.

The multipurpose room was typically a single-room office with space and furniture for individual and group work. Group work usually called for a large table and chairs, possibly a whiteboard, and enough power outlets for the group's numerous devices. Individual work varied a little more. Students often asked for separate arrangements for specific tasks. A typical setup for writing and gathering research materials was a desk with a computer and rolling office chair. For reading, students often drew a comfortable chair, often an armchair, with a lamp nearby to better light their reading materials. This task-based distinction was seen not only in the charrette drawings of ideal spaces but also in other parts of this study that showed how students currently work.

The second type of multifunctional space identified was a suite of rooms dedicated to specific tasks located next to each other. Quite often the suite included a quiet room for individual work, a computer room or lab, a room for group work with a large table and chairs, and some kind of lounge space for relaxation and food storage and preparation. 


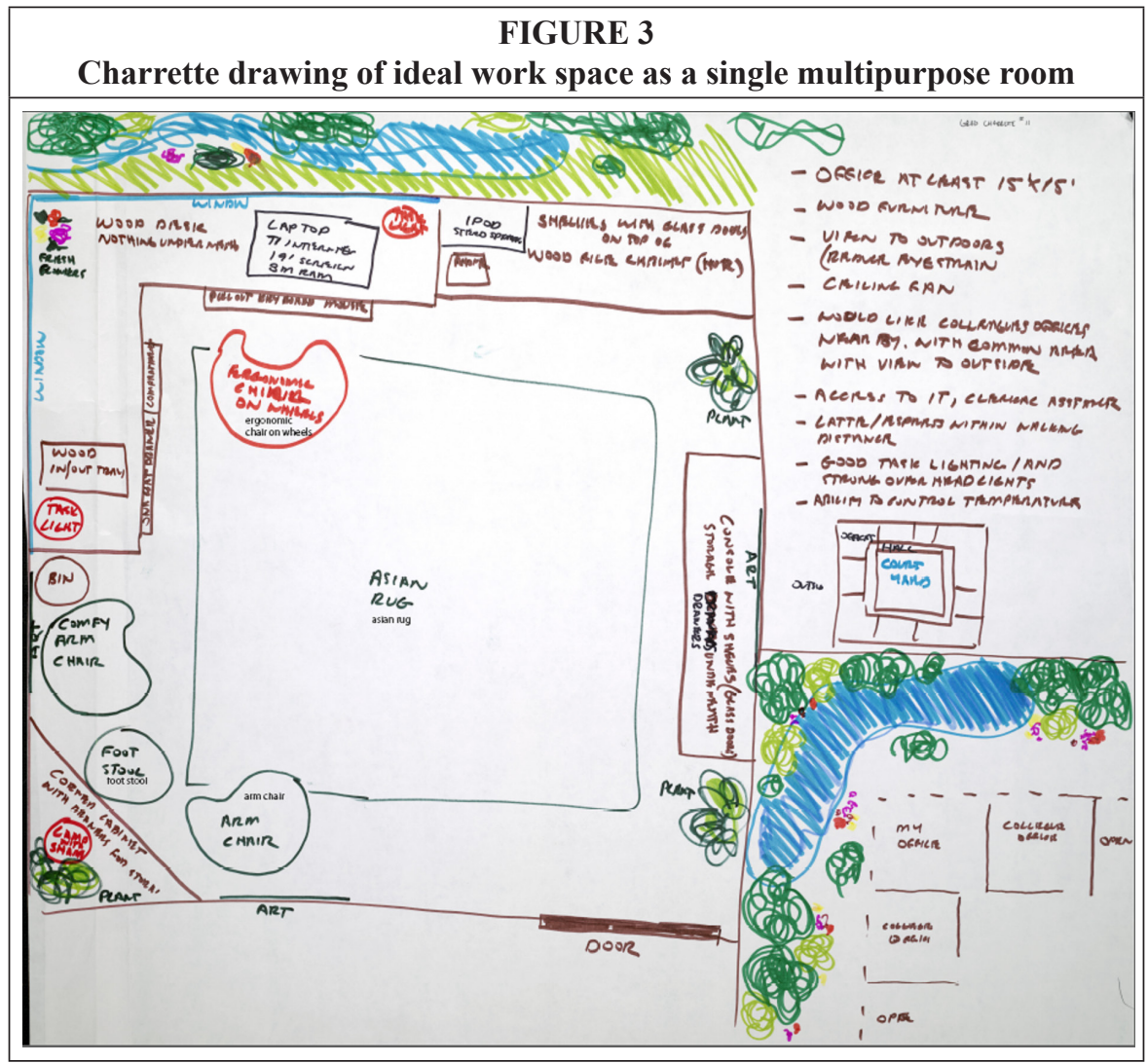

Both of these types of spaces indicate a desire for proximity to all the things and people that students may need while doing their work. In describing her charrette, one student said, "The space that I put together is a mix of everything I could need while studying so I can have all my needs met within one study space."

\section{Atmosphere}

Graduate students typically have a range of spaces available to them: home, departmental spaces, library, other campus locations, and cafes. Each space has different noise levels and types of distractions (such as social distractions like family/roommates, house obligations like laundry and chores, or noise in shared spaces like coffee shops).

The concepts of quiet and distraction are so relevant to graduate students that they are mentioned in all methods employed in the study. Of the students who responded to the survey, 74 percent reported that they were most successful doing academic work in a quiet environment. A word count of the interview and focus group transcripts revealed that "quiet" was mentioned 203 times by 64 students out of a total of 115 . Variants of the word "distraction" were mentioned 199 times by 45 students.

When students talked about distractions, they typically fell into two categories, visual or auditory. Visual distractions included people walking by, window views, clutter, and items on the wall. Some liked to see art on the walls in their work space. Some specifically wanted windows in order to stay connected to day and night cycles or to look at natural scenery like trees, lakes, or green spaces for inspiration. Others found windows distracting from the intense focus required for their work. In one 


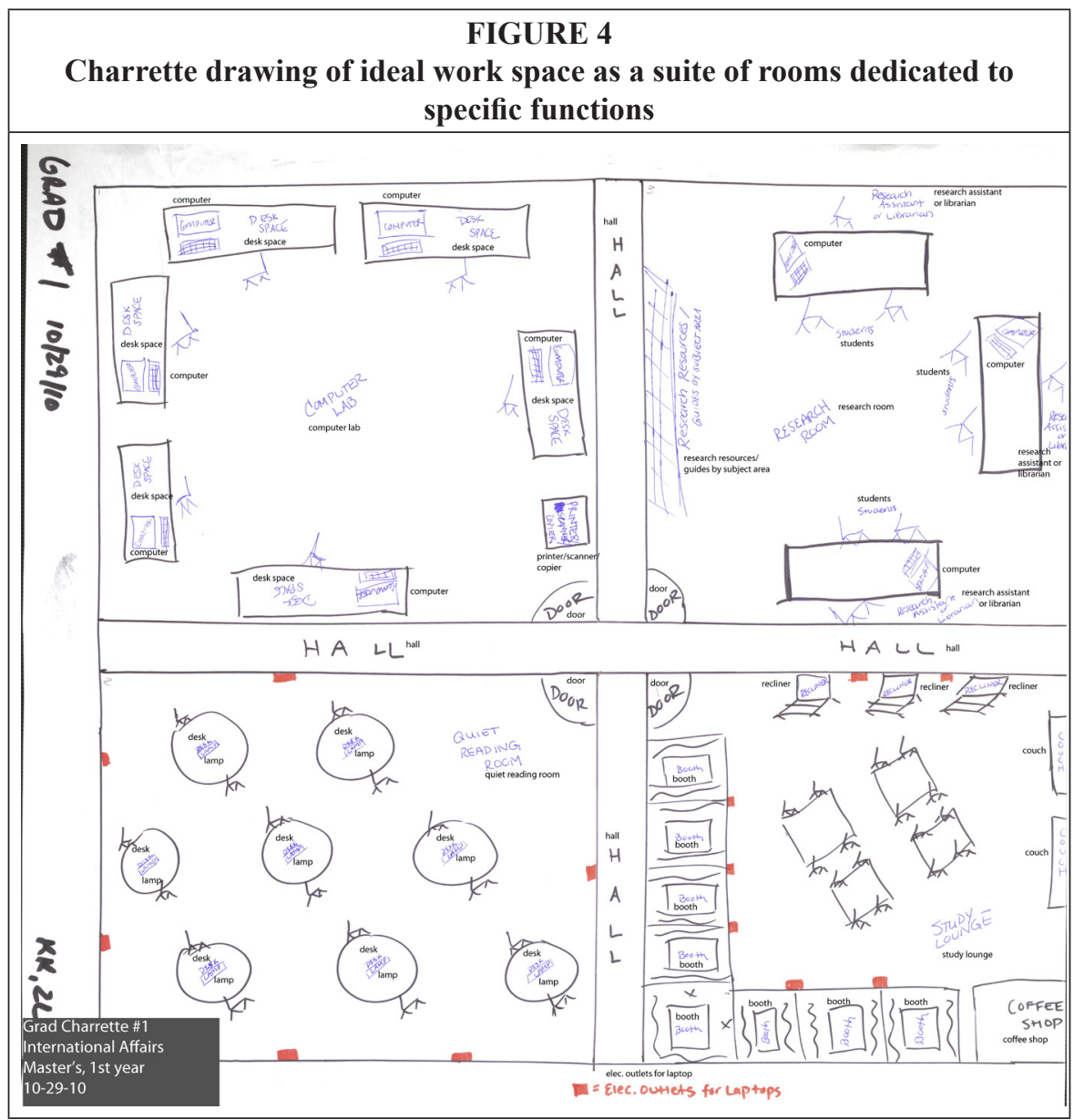

charrette, a student specifically drew the windows behind her desk so that she could focus but have the option of another view between periods of intense work. Strategies for minimizing distractions included not facing shared office desk space or placing desks facing a wall.

Auditory distractions included intrusive sounds, such as people talking. In the survey, graduate students cited loud conversations (76\%) and other people's music or TV $(81 \%)$ as most distracting. Students did not necessarily want absolute quiet all the time. Their preferences ranged over a continuum from absolute quiet to lots of background noise, music, or talking. Research activities determined acceptable noise levels, which in turn influenced where students chose to work. Preferences varied as to what noise level was appropriate for which activity. For example, some students preferred quiet when reading while others preferred moderate ambient noise.

One student describes the individual continuum well:

I am thinking about what we have on campus, for example, Strozier Library, where you come in and you have Starbucks coffee, you can get a little loud and then you can go downstairs and have some quiet time with the graduate students and you know for sure that is the place you can study. I'm looking for something 
that you can actually have direction and if you want to play your music you can do so but at the same time if you need to do something really important... then you have that place.

Wherever the student worked, having the ability to control the level of noise or distraction was desirable. In Phase II, participants expressed a desire for more stringent enforcement of designated quiet spaces in the library. For several people, the inability to predict or control the noise level kept them from using the library.

\section{Graduate-Only Spaces}

Graduate students were often ambivalent in their feelings about the physical library space, valuing graduate-only spaces while expressing frustration with undergraduateoriented spaces. The type of ideal study space described by graduate students differed from the social spaces that interested undergraduates in the FSU study of undergraduate academic work. ${ }^{32}$ Graduate students generally were critical of what they perceived to be a "party" atmosphere perpetuated by undergraduates that resulted in social, sometimes noisy, and crowded spaces in the main library, often referred to as "Club Stroz." A number of students complained about undergraduates using Facebook, socializing, or not engaging in serious work in the library as a distraction and an annoyance.

In interviews, focus groups, and photo diaries, respondents expressed a desire to have a space for study and research that is limited to graduate students. Rempel et al., among others, have also found this same preference for graduate-only spaces. ${ }^{33}$ Elaborating on this idea, several FSU students described the Scholars Commons as a "second home." Significantly, they considered the Reading Room, which is restricted to graduate students and faculty, as a place that is "conducive to real intensive focused study."

During an interview, one student explained his reason for wanting a separate place for graduate students: "There is like a difference, and I know when I was in undergrad I didn't realize it is work...this takes me to my career level, and I don't think undergrads understand that a lot." Being surrounded by other graduate students who are serious about their work is also motivational for some students. "It is helpful to be around other grad students also hard at work even if you are working entirely independently," stated one student in a focus group.

Since studying and writing can be isolating, being around other graduate students engaged in similar work helped lessen feelings of loneliness and isolation for many students. During one interview, a student talked about a group of students who are not in her classes but who study in the same area where she does and who provide a sense of community, a theme seen across the data.

There's some of these second and third year students that I was mentioning that are working on some pretty impressive projects ...they're in the LRC [departmental study space] a lot. ... And I always feel kind of reassured when I see them there because it's like, you know, they're my cohort. We don't actually study together but we're in the same room.

Comments such as this underscore the desire that graduate students in this study felt for a community space. Previous studies have conceptualized the idea of a "third space" that promotes interdisciplinary connections, a sense of community, and offers a social outlet. ${ }^{34}$ This study concluded that, for day-to-day activities, graduate students often seek third spaces where they can be surrounded by other scholars while working independently. 


\section{Room to Spread Out}

Across the study, graduate students consistently chose spaces and furniture that allowed them to spread out. Quite often, students work with multiple resources or documents at a time. This is especially true as students write or synthesize ideas, often using a laptop along with multiple online and print resources. Photo diary pictures show it is not uncommon for office desks at home to be used for storage instead of work as students opt for larger kitchen or coffee tables. Freeze frame images of students at work in campus computer labs show their papers and belongings spread across neighboring computer stations (see figure 5). Wherever students worked, there was a clear preference for laptops and large tables with many outlets available rather than rows of desktops in typical computer-lab fashion.

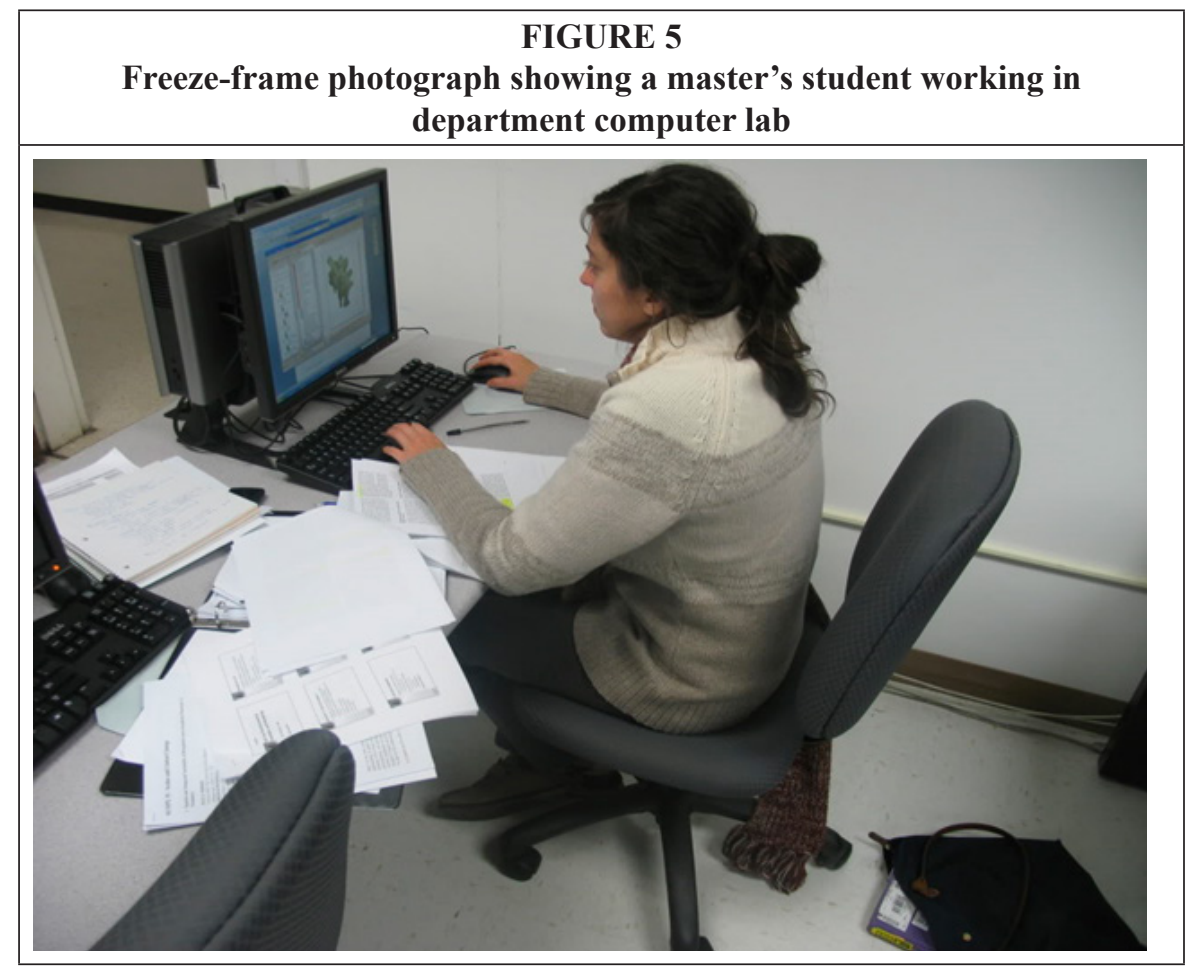

\section{Storage}

Storage was a key issue for many graduate students. In charrettes, students drew bookshelves and filing cabinets to show where their resources would be located. Freeze frames and photo diaries revealed bookshelves and desks overflowing with materials. Students expressed a need for more storage, preferably with some security, since this is not always provided in departmental offices or elsewhere on campus. Students found that having all of the materials needed to complete a task stored in one place helped them to be more successful.

\section{Working Long Hours}

The data showed that graduate students often work for long stretches of time and prefer spaces conducive to working long hours. This impacts such decisions as furniture 
selection. Having a variety of furniture types available was desirable, especially when switching tasks. For example, students preferred desks or large tables with adjustable chairs for writing and comfortable armchairs for reading.

Another consideration when working long hours is access to food and drink. A lack of convenient food and drink options was found to be a barrier to working in the library specifically and on campus generally. While the library has a small, popular coffee shop, graduate students expressed a strong desire for more affordable, healthier food options in close proximity to study spaces. Some department spaces provide a coffee maker, refrigerator, and/or microwave, allowing students to bring their own food, which helps alleviate this barrier. Graduate students reported that they sometimes chose to work at home for easy access to food and drink, especially when working long hours.

\section{Access}

How and when a space is accessible was an important consideration for students when choosing a place to work. In regard to campus locations, students pointed to a host of barriers that affected the way they work. The data suggest that an important factor in a graduate student's life is time. Grad students must be flexible with their schedules, fitting in shorter bursts of study and research time around multiple commitments. Often longer periods for study are set aside either earlier in the morning or later in the evening and night. This means that graduate students find themselves working throughout the day and night and want spaces that are open as much as possible. FSU's main library is open $24 / 5$, but several students complained about not being able to use the library during their prime work time because it closes at $6 \mathrm{pm}$ on Friday and Saturday and opens at noon on Sunday. For many students, Friday evening and Sunday morning are the least busy times of their week, when they can devote several hours to intensive research.

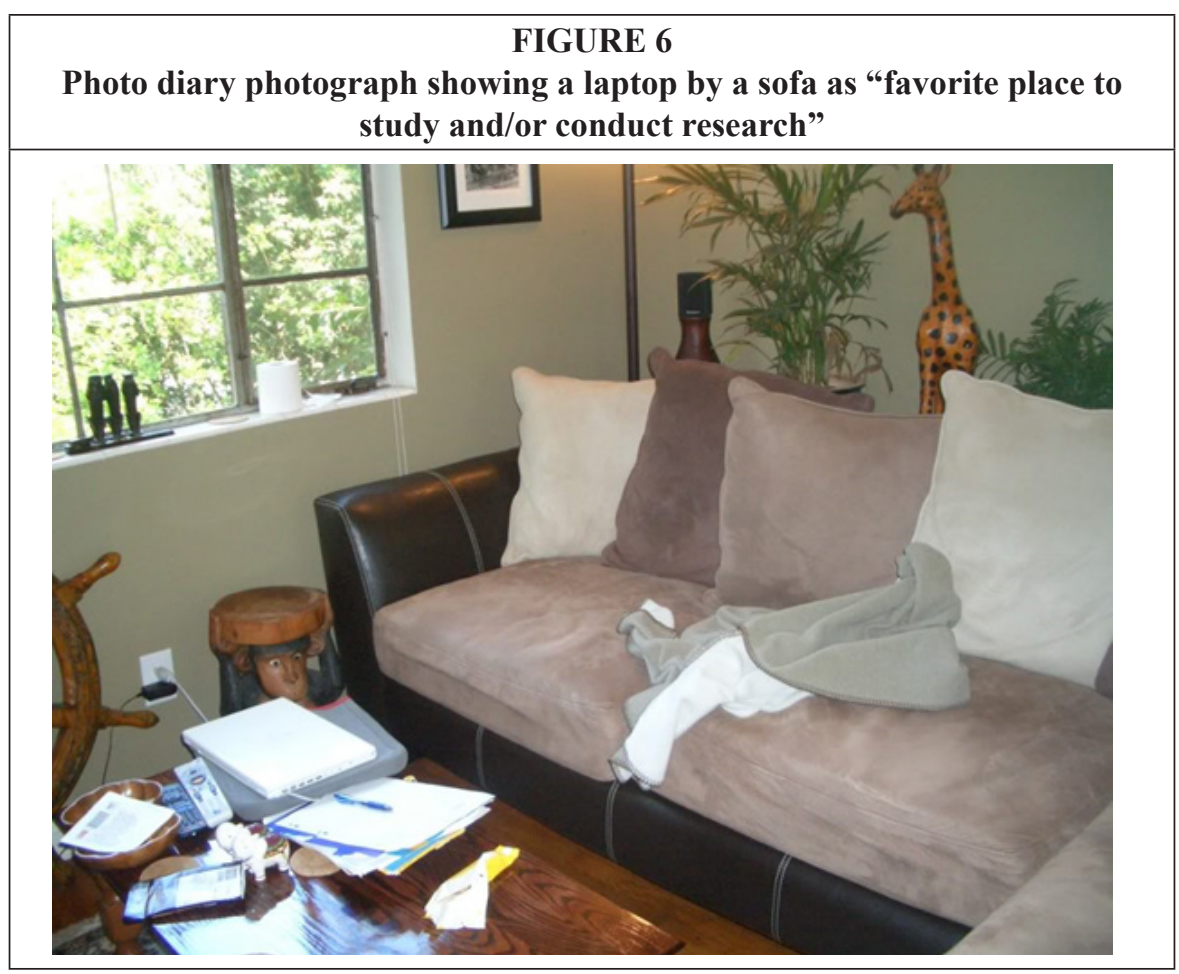


Perhaps the greatest barrier to working on campus, however, is the lack of convenient parking. In her charrette drawing of her ideal campus office space, a student specified the need to have plenty of parking close by "because I won't ever come here if parking is an obstacle." Students often complain about wasting valuable time circling parking lots looking for a spot. Parking is particularly an issue for students wanting to use the library, as most locations are in the center of campus and student parking is being pushed to the outer edges of the campus. In addition to the inconvenience of the long walk, students who work late into the night worry about security when walking back to their cars. Alternatively, many students chose to work at home with a laptop or other Internet-capable device (see figure 6). Several photo diary participants photographed their laptop and sofa in response to the prompt "favorite place to study and/or conduct research."

\section{Conclusions}

When this study was initiated, FSU librarians had certain assumptions about graduate student needs and behaviors. The data from this study both confirm many of the decisions made by FSUL and suggest new ways in which the libraries might serve graduate students. In many ways, there is not a one-size-fits-all behavior or need that would describe graduate students. It appears that a variety of spaces conveniently and seamlessly conjoined to support their academic behaviors and needs is preferable. Librarians are pleased to see that the Scholars Commons has successfully addressed number of these preferences and has become a focal point for graduate students on campus, not only in terms of space for study, research, and workshops, but as a community-building space. Any disadvantages caused by restricting a small percentage of space for the use of graduate students are offset by the clearly demonstrated value.

The results of this study provide a very detailed and nuanced view of graduate students' academic work behaviors and needs. Some of the findings are consistent with those of earlier studies that recognized the diversity among graduate students and the unequal access to resources and spaces provided by different campus units. Unlike previous research, most students were unaware that the study was being conducted by library personnel, yet their responses indicate that the library plays a significant role in their lives. Adding to the collective knowledge about graduate students is the affirmation of library as a third space where they feel a sense of community with other "serious" students. The need for a range or continuum of quiet to meet desired noise levels based on tasks and individual preferences is also clearly evident.

The inequalities between departments pose an opportunity for the libraries to fill in the gaps left by departments that are unable to meet all of the needs of their graduate students. While FSUL already provide a variety of graduate spaces with different levels of noise and minimized distractions, the study shows the need to expand these spaces. The data indicate a desire for additional weekend hours, space to spread out while working, a variety of comfortable furniture, and storage space, which are likely to impact future decisions made by FSUL. Because of the barrier posed by limited parking near the libraries, expansion of the library delivery service to additional groups of graduate students is being considered. In the long term, the data from this study will be used to renovate or create spaces to best fit the needs of graduate students.

This study also suggests additional topics for exploration, either in the data from this study or in new studies. Findings suggest the importance of virtual library space and further research on the effectiveness of the libraries' online presence is needed. Segmenting the results by degree and discipline may reveal different needs and preferences, leading to more customized services for different populations. Additionally, 


\section{Graduate Conversations: Assessing the Space Needs of Graduate Students 769}

focusing on the research needs and gaps identified in this study will help the libraries better support graduate students.

This has proven to be a timely study because of FSU's commitment to new performance metrics, which place a greater emphasis on graduate student enrollment and completion. FSUL will use the data from this study and future explorations to support graduate research and contribute to these institutional priorities.

Reaching out and listening to graduate students is critical for libraries serving this constituency. In addition to providing crucial information for improving or creating spaces or services, it also provides data to use in advocating for graduate students within the library and on campus.

\section{Notes}

1. Florida State University Office of Institutional Research, Budget and Analysis Department, "Five-Year Enrollment by Student Level," Student Enrollment, available online at www.ir.fsu.edu/ studentinfo.cfm?ID=enroll [last modified 29 May 2014].

2. Gloria Colvin, "The Scholars Commons: Spaces and Services for Faculty and Graduate Students," Florida Libraries 53, no. 1 (2010), 6-8, available online at http://diginole.lib.fsu.edu/ scholar_com/5/ [accessed 23 September 2013].

3. Studying Students: the Undergraduate Research Project at the University of Rochester, eds. Nancy Fried Foster and Susan Gibbons (Chicago: Association of College and Research Libraries, 2007).

4. For some examples, see: Lynda M. Duke and Andrew D. Asher, College Libraries and Student Culture: What We Now Know (Chicago: American Library Association, 2012), 9; Tracy Gabridge, Millicent Gaskell, and Amy Stout, "Information Seeking through Students' Eyes: The MIT Photo Diary Study," College E Research Libraries 69, no. 6 (2008): 510-23; Henry D. Delcore, James Mullooly, and Michael Scroggins, "The Library Study at Fresno State" (report, Institute of Public Anthropology, California State University, Fresno 2009); Colin Beard and David Bawden, "University Libraries and the Postgraduate Student: Physical and Virtual Spaces," New Library World 113 (2012): 439-47.

5. David Gibbs et al., "Assessing the Research Needs of Graduate Students at Georgetown University," Journal of Academic Librarianship 38, no. 5 (2012): 268-76; Lindsey Vogt and Brian Mathews, "The Virtual Reality: Exploring Graduate Student Use Patterns at the UCSB Library" (Google document, Santa Barbara, Calif.: University of Santa Barbara, 2011), available online at https://docs.google.com/document/d/1iGIrUTNL_Vd36fE4eqbFB-N-TKrVHuzJC0FwYNRnV18/ edit?hl=en\&authkey=CKr0iLkK\&pli=1 [accessed 24 March 2014]; Todd White, "Enhancing Library Services for Graduate Students: An Ethnographic Study at Colorado State University Libraries" (report, Colorado State University Libraries, 2008), available online at http://hdl.handle. net/10217/3970 [accessed 24 March 2014]; Ryan Randall et al., "The Next Generation of Academics: A Report on a Study Conducted at the University of Rochester" (report, Rochester, New York: University of Rochester, 2008), available online at http://hdl.handle.net/1802/6053 [accessed 23 September 2013].

6. Lucinda Covert-Vail and Scott Collard, "New Roles for New Times: Research Library Services for Graduate Students" (report, Washington, D.C.: Association for Research Libraries, 2012), 9, available online at www.arl.org/storage/documents/publications/nrnt-grad-roles-20dec12.pdf [accessed 23 September 2013].

7. Covert-Vail and Collard, "New Roles for New Times"; Beard and Bawden, "University Libraries and the Postgraduate Student."

8. Covert-Vail and Collard, "New Roles for New Times," 25.

9. Hannah Rempel, Uta Hussong-Christian, and Margaret Mellinger, "Graduate Student Space and Service Needs: A Recommendation for a Cross-Campus Solution," Journal of Academic Librarianship 37 (2011): 480-87.

10. Covert-Vail and Collard, "New Roles for New Times," 25.

11. Covert-Vail and Collard, "New Roles for New Times," 25; Beard and Bawden, "University Libraries and the Postgraduate Student"; Library Assessment Committee, "Boston University 2012 Graduate Student Library Survey Report" (Boston, Mass.: Boston University, 2012), available online at www.bu.edu/library/files/2012/09/2012GraduateStudentLibrarySurveyReport.pdf [accessed 23 September 2013].

12. Covert-Vail and Collard, "New Roles for New Times," 25.

13. Vicki Burns, "Understanding Our Users: Ethnographic Research at the University of Rochester" (PowerPoint lecture slides, Rochester, N.Y.: University of Rochester, November 17, 
2010): slides 51 and 53, available online at https://docushare.lib.rochester.edu/docushare/dsweb/ GetRendition/Document-46580/html\#bmk0 [accessed 23 September 2013]; Randall et al., "The Next Generation of Academics."

14. Susan Hagen, "Graduate Students Get a Room of Their Own," available online at www. rochester.edu/news/show.php?id=3476 [last modified 23 October 2009; accessed 23 September 2013].

15. Ravi Mehta, Rui Zhu, and Amar Cheema, "Is Noise Always Bad? Exploring the Effects of Ambient Noise on Creative Cognition," Journal of Consumer Research 39 (2012): 784-99.

16. Jonathan Hunter and Andrew Cox, "Learning over Tea! Studying in Informal Learning Spaces," New Library World 115 (2014): 47.

17. Agnes Tatarka et al., "Survey of Graduate and Professional School Students" (report, Chicago, Ill.: University of Chicago Library, 2010), available online at www.lib.uchicago.edu/e/ surveys/2010/index.html [accessed 23 September 2013]; Hope Barton et al., "Identifying the Resource and Service Needs of Graduate and Professional Students," portal: Libraries and the Academy 2, no. 1 (2002).

18. Library Assessment Committee, "Boston University 2012 Report," 17.

19 Library Assessment Committee, "Boston University 2012 Report," 17; Jessica Kayongo and Clarence Helm, "Graduate Students and the Library: A Survey of Research Practices and Library Use at the University of Notre Dame," Reference E User Services Quarterly 49, no. 4 (2010). 483.

20. Rempel, Hussong-Christian, and Mellinger, "Graduate Student Space and Service Needs,"

21. Covert-Vail and Collard, "New Roles for New Times," 5, 7.

22. Ibid., 7 .

23. Lynn McAlpine and Nick Hopwood, “Third Spaces': A Useful Developmental Lens?" International Journal for Academic Development 14, no. 2 (2009): 159-62; Lisa Waxman et al., "The Library as Place: Providing Students with Opportunities for Socialization, Relaxation, and Restoration," New Library World 108, no. 9/10 (2007): 424-34.

24. Covert-Vail and Collard, "New Roles for New Times," 6; Hagen, "Graduate Students Get a Room of Their Own"; Waxman et al., "The Library as Place"; Beard and Bawden, "University Libraries and the Postgraduate Student"; Rempel, Hussong-Christian, and Mellinger, "Graduate Student Space and Service Needs."

25. Foster and Gibbons, Studying Students; Duke and Asher, College Libraries and Student Culture.

26. A separate study looked at the needs and behaviors of STEM graduate students. 43.

27. William Edwards Deming, Some Theory of Sampling (New York: Dover Publications, 1966),

28. Phase I also included a GPS mapping pilot assessment that will not be included in the present analysis but will be discussed in a separate article.

29. Covert-Vail and Collard, "New Roles for New Times"; Rempel, Hussong-Christian, and Mellinger, "Graduate Student Space and Service Needs," 480. 483.

30. Rempel, Hussong-Christian, and Mellinger, "Graduate Student Space and Service Needs,"

31. All quotations in the Results and Discussion section refer to the study data unless otherwise noted.

32. Rachel Besara, Kirsten Kinsley, and Rebecca Bichel, "Studying the Florida State University Community: A FSU Libraries' Endeavor to Understand \& Engage Our Users Summer 2008-2010" (working paper, University Libraries, Florida State University, Tallahassee, n.d.), available online at https://www.lib.fsu.edu/sites/default/files/overviewoffsulibrariesassmnt.pdf [accessed 14 October 2014]. 481.

33. Rempel, Hussong-Christian, and Mellinger, "Graduate Student Space and Service Needs,"

34. McAlpine and Hopwood, "Third Spaces"; Waxman et al., "The Library as Place"; CovertVail and Collard, "New Roles for New Times"; Rempel, Hussong-Christian, and Mellinger, "Graduate Student Space and Service Needs." 